\title{
Model Development of Quality Management Education Invocational Schools in Bandung
}

\author{
Endang Herawan \\ Universitas Pendidikan Indonesia \\ Bandung, Indonesia \\ Endangh.upi@gmail.com
}

\author{
Dedy Achmad Kurniady \\ Universitas Pendidikan Indonesia \\ Bandung, Indonesia \\ Dedy_achmad@upi.edu *)
}

\begin{abstract}
This research was conducted on the basis of the observation that the obtained information that there are some vocational graduates have been able to compete with graduates of higher education, but it is still a small part only and that too for graduates who do have willpower and high creativity. Although school learning innovation, and the carrying capacity of the business world and industry allegedly increased but still raises issues that seem to repeat the last problem.Model of Quality Management Education Development relation to the effectiveness of the implementation of vocational education in Bandung.The results of this interim study found that in principle, the school already has a quality management model, by developing a quality assurance system based on ISO 9001: 2008. However, the new system was limited to the procedures and requirements for accreditation and attract interest to users of educational services, it has not been fully become the foundation or basis in running the educational process that can produce graduates according to the needs of business world and industry.Based on this, it is only logical research related to the development of quality management model of education in vocational is necessary for consideration and referral in order to further improve the quality educational outcomes.
\end{abstract}

Keywords: Quality Management, Quality Planning, Quality Control and Quality Assurance

\section{INTRODUCTION}

Human resource development in Indonesia is still less leads to the expected conditions. It can be seen from the mastery of competencies and the resulting labor productivity is still low compared to other countries in Southeast Asia region, so that Indonesian workers hard to compete, even some job opportunities that exist in Indonesia filled by foreign workers.Based on observation, although there are some vocational graduates have been able to compete with graduates of higher education, but it is still a small part only and that too for graduates who do have willpower and creativity.

Despite the perceived quality of vocational education is still less than satisfactory, but the vocational school is one which is believed capable of creating educational products that are innovative, creative, and productive (Supriadi 2002:17-18). ${ }^{[1]}$ This is because the vocational education aims to produce a productive human, namely labor, not human burden for the family, community, and nation. Because the levels of vocational schools is one of the best alternatives in order to improve the overall quality of Indonesian human.

Quality education is characterized by graduates who have the competence and be able to compete in a business world that is born of the implementation of good education quality management. Answering the challenge of employment issues required vocational education institutions that are reliable and capable of implementing TQM. The ability of vocational schools to implement quality management, at this moment as an obligation, so that the graduates produced by the institution is able to overcome the problem of unemployment and employment are still complained of by the business/industrial world.

The focus of this research is the implementation of quality management at vocational schools Business Management group, namely SMK Negeri 1, SMK Negeri 3 , and SMK Pasundan 1. Vocational school as an educational institution that serves to prepare students for work or selfemployment and to follow further education, should be able to provide quality education services, which can meet the expectations and needs of external customers, ie business / industry and internal ie students.

Quality services provided by the school can be seen from the aspect of education as a system, ie 1) Input, which include: vision, mission, goals of the school, policies, curriculum or learning programs, learning facilities, the formulation of standards of competence, professional teaching force. 2) The process or learning strategies developed by the school or the teacher, which includes the use of learning strategies and evaluation as well as the business community's participation in the planning, teaching and learning process implementation and evaluation of learning. 3) Supervision and control system, which includes determination of the scope of supervision, control strategies, follow-up control in the form of efforts to increase and improvements in the formulation of the competence of the students, the curriculum, the implementation of the learning process and learning evaluation system so that it addresses the needs of the workforce and society.

\section{A. Problem Statement}

Research problem statement will be described in the following research question is:

1. How is quality planning conducted by leaders of the vocational school in Bandung? 
a. Quality guidelines on what basis in preparing graduates who have the ability to work, continuing education and entrepreneurship?

b. The quality policy is set by leaders of the vocational school in Bandung in preparing graduates who have the ability to work, continuing education and entrepreneurship?

c. The formulation of the standard of competence students what are defined by a vocational school in Bandung?

2. How is the implementation of quality management conducted by a vocational school in Bandung in preparing graduates to have the ability to work, continuing education and entrepreneurship?

a. What curriculum developed?

b. How does the curriculum implementation strategy implemented?

3. How does the supervision and control system of the quality management conducted by a vocational school in Bandung in order to maintain consistency in preparing graduates to have the ability to work, continuing education and entrepreneurship?

a. How the learning process is carried out?

b. How to evaluate learning result implemented?

c. How is supervision conducted?

4. How does quality assurance implemented in vocational school in Bandung?

5. How is the development of quality management model of education vocational school in Bandung which can be recommended?

\section{B. Objective}

The purpose of this research is to find out which related to:

1. Verify, describe and interpret data about quality management plan related to the quality manual, quality policy, standard operating procedures, and the formulation of student competency standard set by leaders of the vocational school in Bandung in preparing graduates who have the ability to work, continuing education and entrepreneurship.

2. Verify, describe and interpret the implementation of quality management related to curriculum and strategy set by the vocational school in Bandung.

3. Verify, describe and interpret the system of supervision and control related to the learning process, evaluation of learning result, and supervision developed by vocational school in Bandung in preparing graduates who have the ability to work, continuing education and entrepreneurship.

4. Verify, describe and interpret the quality assurance conducted by vocational school in Bandung.

5. Describe the quality management model vocational school education in Bandung which can be implemented

\section{METHODOLOGY}

This research is using qualitative approach, as it aims to describe and analyze the implementation of the quality management of vocational school in Bandung, especially those held in SMK Negeri 1, 3 and SMK Pasundan 1. In this research, researchers are trying to understand, comprehend and studied in depth the school administrators in an effort to improve the quality or relevance through the implementation of quality management, then interpret, make sense of phenomena and events that correspond to the problems examined.

\section{RESULT AND DISCUSSION}

\section{A. Quality plan of vocational school in Bandung}

In carrying out the process of education at the vocational school level, principals conduct quality planning measures relating to the management of school. Quality planning in school that observed more emphasis on curriculum components. This is done because of the clarity of the curriculum will involve the provision and availability of resources should be owned by the school, in favor of teaching and learning process in accordance with the needs student learning.

Related quality planning in vocational school, especially in vocational school in the observation established a variety of programs, including:

1. Improving the competence of teachers, through OJT (on the job trainning), the internship program aimed at teachers of productive sectors, for the apprentice school in collaboration with various companies, eg with Yogya Department Store, which lasted 3 months.

2. An internship program for graduate candidates, which is addressed to all third level students, for those who are interested in doing internship atThe world of business and industry while awaiting results of national examinations ratings.

3. The training program by The world of business and industry for the students, for example, by Yogya department store.

4. Program to improve the quality and quantity of facilities.

5. Inventory and select institutions or The world of business and industry which will be a place of industrial work practices. OJT Institute place that really could provide experience in accordance with the competencies set out in the journal prakerin.

6. Also invite guest teachers, from professional associations. For example, for accounting majors from AAI (Association of Indonesian Accountants), Administrative Office from ISI (Association Secretary Indonesia) and the Association of Indonesian Travel.

7. Development journal in which the implementation Prakerin get input from The world of business and industry, especially the input in the determination of student competencies that will be developed during Prakerin. OJT principle is student learning from the 
field and not to apply the theory learned at school in the field. Lasted for 3 months.

8. Before students conduct OJT, students are prepared in advance, through program Beauty Class. This activity lasted for 3 days. Materials provided related attitudes or behavior in the work, the appearance, which includes procedures for makeup, dressing and communicate.

9. Development of competency matrix. Competencies identified in the matrix which could be developed at school and at The world of business and industry.

10. Job Matching or Job Ekspo Program.

11. Cooperation with The world of business and industry in setting criteria for prospective students.

\section{B. Implementation of quality management of vocational school in Bandung}

Based on the observation that has been made in vocational school which became the object of research, implementation in how to manage quality, in principle refers to the policy defined by the government based on the Minimum Management Standard and National Education System Law 2003. ${ }^{[2]}$

In order to improve the results of graduates in accordance with the needs of business and industry, or graduates can have the ability to work, continuing education and entrepreneurship, every school in the observation implement a quality management system based on ISO 9001: 2008. ie those related to the requirements of the quality management system. Where schools implement measures of the quality management system as follows:

a. Identification of the service process / business / education

b. Establishing the quality policy

c. Establish quality objectives and quality management plan

d. Identify the need of the document

e. Create a document of guidelines and quality procedures

f. Create a document of work instruction

Once this is done, then the school carry out the implementation of quality management system, as follows:

a. Socialization of documents used

b. Implementation of quality system documents

c. Monitoring the application of ISO 9001

d. Conduct a review of management

e. Collect notes

f. Create a performance report of ISO 9001

\section{Supervision andcontrol system of quality management}

The principal jointly with the deputy principal curriculum areas carry out supervision or oversight of all components of existing resources in the school, which aims to ensure that implementation of the curriculum and learning programs at vocational schools can be run in accordance with the plans and defined objectives.
In interviews with the principals and their deputy principal, that the supervisory activities carried out in the form of filling sheet monitoring, or a journal of activities in the classroom, as well as the principal or vice routinely monitor the performance of teachers teaching through CCTV monitor (for schools that are already equipped with the tools), or every morning around to each classroom to see the presence of the teacher in the classroom. Furthermore, the principal or vice-principal to collect and examine the administrative class, syllabus and lesson plans created by teachers. While this activity class visitation has not been thoroughly done, because it feared could disrupt the concentration of the teachers who are teaching and students are learning.

Mechanical supervision conducted by principals and vice-principals, using the in-formal approach, that is by asking directly to the students about the appearance of teachers when teaching. Principals assume that the information submitted by the students is very important, because students as internal customers are the first to feel directly on the quality of services provided by the teacher as the implementation of a program of learning at school.

Results of monitoring school principal regularly followed up, by convening a meeting or a meeting with all the teachers in order to provide guidance, as well as informally submit corrections to the performance of teachers in the classroom teaching, teacher administration which includes the preparation of syllabus and lesson plans. In addition, principals remind and motivate teachers to always carry out its duties and functions with a sense of responsibility.

Supervision and monitoring activities not only on the implementation of education in schools, but performed well on the activities of the working practices of the industry. The activities conducted by the teacher, who was assigned as a supervisor. In the implementation, monitoring activities are performed at least three times, or tailored to the needs of the field.

Implementation of monitoring conducted by teachers, conducted by bringing the monitoring sheet. Wherein each monitoring activities, teachers have to explore to get information about student activities, the ability to carry out the job duties, the behavior and the problems faced by students during practice in the industry. In addition, teachers should try to get feedback from business / industry, both regarding capability and performance of students, as well as prakerin program prepared by schools. Suggestions from business / industry serve as feedback for the school to repair or improvement of the curriculum, the formulation of competence as well as for improving the management of prakerin program itself. Thus the school to make improvements continuously. This improvement efforts conducted by the principal through meetings with teachers, or a meeting with business / industry, also provides the opportunity for any programming skills to make improvements in accordance with the inputs submitted by the business / industry. 


\section{Quality assurance of vocational school in Bandung}

Quality assurance of education in the vocational school environment, is intended to maintain and improve the quality of education in a sustainable manner, which is run by an educational institution internally to realize the vision and mission, as well as to meet the needs of stakeholders through the organization insight wyata mandala. Target of the objectives of quality assurance through quality assurance activities undertaken internally by the school, will be controlled and audited through accreditation activities run by BAN-PT or other external agencies. Thus, the objectivity of an assessment of the maintenance and improvement of the quality of vocational education can be realized in a sustainable manner.

Quality assurance of education in vocational schools, organized through a variety of quality control management model. One of the management model applied and used model is the PDCA (Plan, Do, Check, Action) which will result in continuous improvement.

\section{E. Recommendation development of education quality management model of vocational school in Bandung}

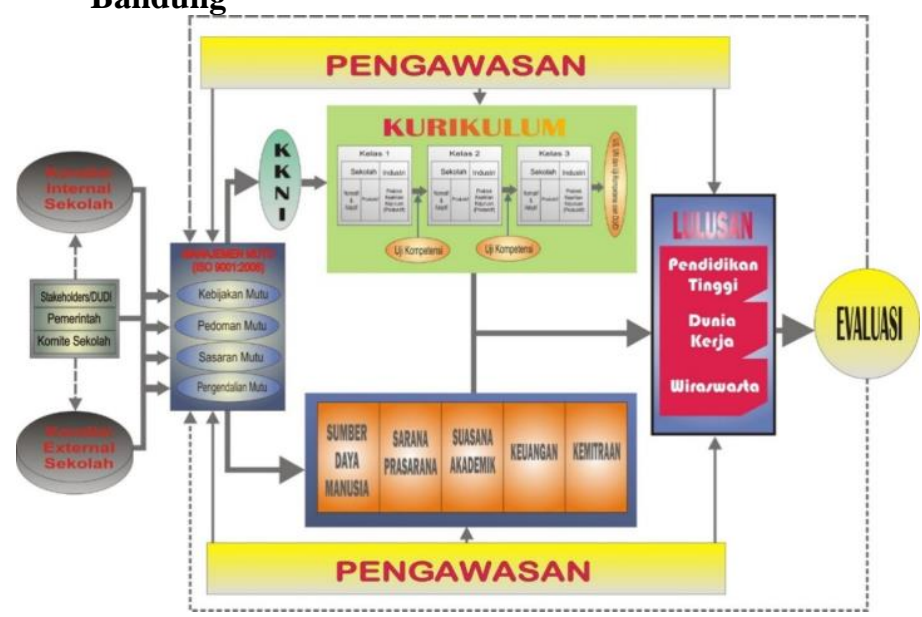

Figure 1. Quality Development Hypothetical Model of Vocational School

Based on the hypothetical model that has been described, the following described workflow hypothetical model the development of quality vocational school in Bandung, which can be recommended, as follows.

Vocational school is the level of formal school has its own characteristics there is even a philosophy that sees vocational education, who should be responsible for the preparation of people to work, with the philosophy of this will have an impact, which should be available in various types of education that serves to prepare people for work.

Vocational school as an educational institution that serves to prepare students for work or self-employment and to follow further education, should be able to provide quality education services, which can meet the expectations and needs of external customers, ie business / industry and internal ie students. Quality services provided by the school can be seen from the aspect of education as a consistent, namely 1) Input, which include: vision, mission, goals of the school, policies, curriculum or learning programs, learning facilities, the formulation of standards of competence, professional teaching force. 2) The process or learning strategies developed by the school or the teacher, which includes the use of learning strategies and evaluation as well as the business community's participation in the planning, teaching and learning process implementation and evaluation of learning. 3) Supervision and control system, which includes determination of the scope of supervision, control strategies, follow-up control in the form of efforts to increase and improvements in the formulation of the competence of the students, the curriculum, the implementation of the learning process and learning evaluation system so that it addresses the needs of the workforce and society.

Quality planning includes quality guidelines, quality policy and the formulation of standards of competence of students. Involvement The world of business and industry in the educational process, allowing students to have a more concrete learning experience, so it will be a provision that is invaluable in work, entrepreneurship and continuing education.

Development of quality management model in vocational schools using CIPP evaluation approach are Contex, Input, Process and Product. It selected since this model is considered as a model that emphasizes not on proving, it improves a development and improvement.

Evaluation context include analysis of issues related to the environment program or objective conditions to be implemented, in this case the model of development of quality analyze internal and external conditions in schools, seeing the condition of the stakeholder, school committees and governments with the aim to create a quality planning which will applied. Stakeholders will have an impact on the application of quality in vocational schools because stakeholders is the person who will accept graduates of vocational school graduates so that the standard of stakeholders into consideration in the planning of quality. The school committee was instrumental in drafting the quality of school because school committees are community representatives who will answer the final results of the vocational graduates required by society. The government is also taking part in the planning of quality to identify what needs are unmet in the implementation of school quality. To get the quality of qualified graduates, the quality of education and graduates must be repaired. Improved quality of graduates can only happen if preceded improving the quality of education in the school environment that involves stakeholders, school committees and governments.

The quality of school is education goals and competency of graduates that have been assigned by the school in its strategic plan or have incompatibility between the goals of education conducted by academic standards specified. It departs from the concept of quality assurance, that the school is declared qualified if it has the ability to define and realize the vision through the mission and the ability to meet 
the needs of stakeholders that includes the needs of society needs, industrial needs and professional needs. Vision, mission and objectives of the expectations outlined in the guidelines of the quality of schools, the quality policy, quality objectives, and quality control. Vocational education is essential for and must relate to the productivity if people, not only in competence, but in attitude towards one's occupation and willingness to produce" As mentioned of Shoemaker in Suharsimi (1988:242). ${ }^{[3]}$

School quality manual is a reference in running the educational process at school. Quality manual is a guide for every school to implement and achieve that expected quality. Broadly speaking, the quality manual include terms and definitions used by the school, regulations, laws, accreditation standards, certification program and support services, or can be regarded as a quality management system.

The quality policy is a commitment of quality, as outlined in a formal statement that showed a determination to always provide the best to stakeholders. Formulation of the quality policy, referring to the vision, mission education set by the school and national education goals for each school. Schools need to ensure the quality policy conceived by all personnel and become a reference in the determination of targets, preparation of planning and evaluation. In an effort to realize the quality policy, the principal asked all parties, such as: the chairman of the study program, vice-principals, teachers, counseling guidance, manager of Job Market to draw up program and quality objectives to be reached. Achievement of these quality objectives will be an indicator of success of the policies that have been defined. To reach quality objectives contained in the quality manual quality control is needed by all stakeholder school. Quality guidelines, policies, objectives and quality control will adopt several strategies to improve the quality of human resources, improve the effectiveness and efficiency of the performance of schools, improve education facilities and infrastructure. And improve welfare. Some policies set by principals, aimed at aspects of the curriculum, organization and management, personnel, infrastructure, financing, student affairs, industrial relations and the environment/culture of the school. The concepts and principles of the standard are intended to be applicable to all forms of services. (Tenner \& Detoro: 1992:241) ${ }^{[4]}$

Policies in the areas of curriculum, related to curriculum development according to the needs, planning/learning program which refers to the national standard vocational guidance, the implementation of multi methods and media in learning, to encourage creativity and innovation in the learning process, the development of the evaluation system. Competency standards are set at a vocational school does not only refer to SKKNI and demands of the industry or the company, but rather to consider the input of a number of business / industry in similar areas of expertise with various characteristics and conditions that are very diverse. especially in setting the standards for the field of productive the school would invite various business/industry, as well as professional organizations, such as: IAI (Institute of Accounting Indonesia) ISI (Association Secretary Indonesia) ASITA (Asociation of Indonesian Tour and Travel Agency), as well as elements of universities that has a course that is relevant to existing programs in vocational skills. This approach is made possible through the formulation of competencies defined in general can describe or represent a variety of the main demands of the business/industry that became graduates of vocational competence standards.

Policy in the field of personnel, associated with efforts to increase the professionalism of teachers, whether related to his expertise as well as in foreign language acquisition. The quality policy must be supported by teachers who have a powerful ability, commitment, and dedication to work high, supported by reliable human resources are expected to be realized learner program effectiveness. Support of facilities and infrastructure that excellent, accompanied by governance orderly allows school programs can run well, and with the support of the high business / industrial, the expected educational programs using the system multiple run effectively, which in turn is expected that students who graduate completing the program of study may have competencies that can meet the expectations of business / industry, that in turn demand for skilled workers in vocational schools could be increased. Policy in the field of educational facilities, with regard to addressing the needs of educational facilities and optimal use of existing facilities. Policies in the areas of financing, the allocation of funds for development activities of personnel, curriculum development, student programs, research of graduate searches. While policies related to industrial relations geared to fostering cooperation with the school business / industry, efforts to improve the marketing of graduates. Policies in the areas of organization and management directed at developing an organizational structure that is characterized by a the working mechanism and job descriptions as well as the development internet and SIM. Whereas in the field of student affairs policies aimed at improving the quality of the competency test, coaching students through extracurricular activities and tutoring as an effort to improve the quality of learning outcomes, the development of new admissions system that can encompass students that have the potential and interest to participate in vocational education.

The overall process of achieving quality needs to be monitored so that no irregularities occurred in the achievement of quality objectives. The main quality objectives is to prepare graduates to continue their education to higher education, entering the world of work and selfemployment. the final stage of a quality assurance is the evaluation of all activities carried out causing feedback and improve the quality improvements in the next.

The evaluation conducted by the school as a whole is intended to preserve and identify the factors that allow to further improve the quality of education on an ongoing basis. Evaluation is intended to establish and implement a process of continuous improvement of the quality 
management system that has been done, so it will provide input or reciprocity in setting quality objectives, quality manual, quality policy and quality control as well as the quality of the ongoing process. This is necessary because it will affect the learning curriculum and increasing the quality of good resources are good resources teachers, facilities and finances to be able to create the environment and a conducive academic atmosphere, so that the vocational school graduates become graduates who are ready to compete well in continuing school as well as in enter the workforce or to make his own efforts. Thus the final stages of a quality assurance is the evolution of all the activities carried out, giving rise to feedback and improve the quality improvements in further. Quality professionals are primarily responsible for designing the performance information system and assuring compliance with quality-logging requirements. (Mauch, 2010:45) ${ }^{[5]}$

\section{CONCLUSION}

Quality management model that is currently performed by schools examined, in principle has been implemented in accordance with the rules and guidelines in improving the quality of education. However, there are still obstacles in terms of adjusting the results of graduates with relevant parties such as with business and industry, where graduates after graduation were still require additional science or experience in accordance with the needs of business and industry.

This happens because, during the OJT, there are some students that do not correspond to the fields that should be the focus of skills development in accordance with department has chosen. In addition, the quality policy and implementation strategy to implement new quality assurance is seen as a slogan or just to meet the accreditation requirements only, not entirely the school in question refers to the quality policy that has been set in the operational running of education to improve the quality of education.

\section{REFERENCES}

[1] Dedi Supriadi (Editor) (2002). Sejarah Pendidikan Teknik dan Kejuruan di Indonesia: Membangun Manusia Produktif, Dirjen Dikdasmen, Diknas,

[2] Direktorat Jenderal Pendidikan Tinggi, (2003), Pedoman Penjaminan Mutu Perguruan Tinggi, Jakarta : Depatemen Pendidikan Nasional

[3] Suharsimi Arikunto (1988). Organisasi dan Administrasi Pendidikan Teknologi dan Kejuruan. Penerbit P2LPTK Jakarta.

[4] Arthur R. Tenner \& Irving J. Detoro (1992). Total Quality Management. Three Steps To Continous Improvement. Addison-Wesley Publishing Company.

[5] [5] Peter D. Mauch (2010). Quality Management.

[6] Theory and Application. CRC Press.

\footnotetext{
${ }^{*}$ Corresponding Author
} 